\title{
Tuberculosis in Liver Transplant Recipients: A Report of Eight Cases During a Five Year Period
}

\section{Tuberculose em Transplantados Hepáticos: Uma Série de Oito Casos Durante um Período de Cinco Anos}

\author{
Diana PÓVOAS $\rrbracket^{1}$, João MACHADO1,2, Rui PERDIGOTO², Ana MORBEY², Júlio VELOSO², Helena GLÓRIA², \\ Élia MATEUS ${ }^{2}$, Américo MARTINS ${ }^{2}$, Fernando MALTEZ ${ }^{1}$, Eduardo BARROSO ${ }^{2}$ \\ Acta Med Port 2017 Jan;30(1):41-46 - http://dx.doi.org/10.20344/amp.7052
}

\section{ABSTRACT}

Introduction: Tuberculosis incidence in Portugal ranged from 20 to 22 cases per 100000 inhabitants between 2010 and 2014 . Tuberculosis incidence in liver transplant recipients is not precisely known, but it is estimated to be higher than among the general population. Tuberculosis in liver transplant recipients is particularly challenging because of the atypical clinical presentation and side effects of the antibacillary drugs and their potential interactions with immunosuppressive therapies.

Material and Methods: We retrospectively reviewed the clinical records of liver transplant recipients with post-transplant tuberculosis occurring from January 2010 to December 2014 at a liver transplantation unit in Lisbon, Portugal. Demographic data, baseline and clinical features, as well as treatment regimen, toxicities and outcomes, were analyzed.

Results: Among 1005 recipients, active tuberculosis was diagnosed in eight patients between January 2010 and December 2014 (frequency $=0.8 \%$ ). Late onset tuberculosis was more frequent than early tuberculosis. Mycobacterium tuberculosis complex was isolated from cultures in almost every case $(7 ; 87.5 \%)$. Extra-pulmonary involvement and disseminated tuberculosis were frequent. Two patients developed rejection without allograft loss. Crude mortality was $37.5 \%$, with 2 deaths being related to tuberculosis.

Discussion: Despite the uncertainty regarding treatment duration in liver transplant recipients, disease severity, as well as number of active drugs against TB infection, should be taken into account. There was a need for a rifampin-free regimen and immunosuppression adjustment in patients who experienced acute graf rejection.

Conclusion: Although the number of cases of tuberculosis is low, its post-transplant frequency is significant and the observed mortality rate is not to be neglected. The cases of hepatotoxicity and graft rejection seen in this case series demonstrate the challenges associated with tuberculosis diagnosis in liver transplant recipients and management of the interactions between immunosuppressors and rifampin. This study strengthens the recommendation of latent tuberculosis infection screening and treatment in liver transplant candidates or recipients.

Keywords: Liver Transplantation; Mycobacterium tuberculosis; Portugal; Tuberculosis

\section{RESUMO}

Introdução: A incidência de tuberculose em Portugal entre 2010 - 2014 foi de 20 a 22 casos por 100000 habitantes. A incidência de tuberculose em transplantados hepáticos não é conhecida, estimando-se que seja mais elevada do que a da população em geral. $\mathrm{O}$ manejo da tuberculose em transplantados hepáticos constitui um desafio, não só pela apresentação clínica frequentemente atípica, mas também pelos efeitos secundários da terapêutica antibacilar e suas interações farmacológicas com a medicação imunossupressora, necessária no período pós-transplante.

Material e Métodos: Os autores fizeram uma revisão retrospetiva dos casos de doentes transplantados hepáticos com tuberculose pós-transplante diagnosticada durante o período entre janeiro 2010 e dezembro 2014 num centro de transplantação hepática em Lisboa, Portugal. Foram analisados os dados demográficos, características clínicas, a par do regime antibacilar, toxicidade e evolução. Resultados: Num total de 1005 transplantados foi diagnosticada tuberculose ativa em oito doentes entre janeiro de 2010 e dezembro de 2014 (frequência de 0,8\%). O desenvolvimento de tuberculose tardia foi mais frequente do que a doença precoce. Foi isolado Mycobacterium tuberculosis complex no exame cultural de sete doentes $(87,5 \%)$. Foram frequentes a presença de envolvimento extrapulmonar, assim como doença tuberculosa disseminada. Dois doentes desenvolveram rejeição aguda, sem perda de enxerto. A taxa de mortalidade global foi de $37,5 \%$, com duas mortes directamente atribuíveis à tuberculose.

Discussão: Apesar da incerteza quanto à duração do tratamento da tuberculose em transplantados hepáticos, deverão ser tidos em conta a gravidade da doença, assim como o número de fármacos com actividade antibacilar. Nesta série, os doentes que desenvolveram rejeição aguda necessitaram da utilização de um regime sem rifampicina, e ajuste da terapêutica imunossupressora.

Conclusão: Apesar do baixo número de casos de tuberculose, a sua frequência pós-transplante é significativa e a mortalidade associada não é negligenciável. Os casos de hepatotoxicidade e rejeição de enxerto demonstram os desafios no diagnóstico da tuberculose em transplantados hepáticos e a dificuldade do manejo das interações entre imunossupressores e a rifampicina. Este estudo reforça a recomendação de rastreio e tratamento de tuberculose latente em transplantados ou candidatos a transplante hepático.

Palavras-chave: Mycobacterium tuberculosis; Portugal; Tuberculose; Transplante de Fígado

\section{INTRODUCTION}

Tuberculosis (TB) remains a serious opportunistic infection that may affect transplant recipients. TB infection prevalence in liver transplant recipients is uncertain, with

reported rates ranging from $1 \%$ to $6 \%$ in some case series. ${ }^{1,2}$ Most TB cases occur as a result of disease reactivation, most frequently within the first year after transplantation, when

1. Serviço de Doenças Infecciosas. Hospital de Curry Cabral. Lisboa. Portugal.

2. Centro Hepato-Bilio-Pancreático e Transplantação. Hospital de Curry Cabral. Lisboa. Portugal.

$\square$ Autor correspondente: Diana Póvoas.d.povoas@gmail.com

Recebido: 02 de outubro de 2015 - Aceite: 20 de junho de 2016 | Copyright @ Ordem dos Médicos 2017 
immunosuppression is maximal. ${ }^{1}$ Although pulmonary TB occurs in $50 \%$ to $60 \%$ of transplant recipients, disseminated forms are not uncommon. ${ }^{3,4}$ Diagnosis requires a high degree of suspicion and is often delayed, since only a small percentage of transplant recipients present the classic TB symptoms. ${ }^{5}$

\section{MATERIAL AND METHODS}

This retrospective study was conducted in a liver and pancreas transplantation unit at Hospital Curry Cabral in Lisbon, Portugal. This unit performed 1428 liver transplants beteween 1992 and 2014, which roughly corresponds to $40 \%$ of liver transplants performed in Portugal throughout that period. Liver transplant recipients diagnosed with TB during the period from January 2010 to December 2014 were included. Patients' records were reviewed for baseline characteristics, country of origin, immunosuppressive regimen, latent TB screening or evidence of previous TB infection, site of Mycobacterium tuberculosis ( $M$. tuberculosis) infection, clinical, epidemiological and radiographic features, HIV screening, diagnostic procedures, post-transplantation time to diagnosis, treatment, clinical outcomes and mortality.

TB diagnosis was made either by culture of $M$. tuberculosis complex or by presence of a caseous granuloma on histology of a biopsy specimen. Disseminated TB was considered when $M$. tuberculosis was isolated from two or more noncontiguous organs or when there was isolation of M. tuberculosis from one organ along with demonstration of acid-fast bacilli or granulomas at a different site.

Crude mortality was defined as all deaths occurring during follow-up. Mortality was considered to be tuberculosis-related when death occurred during the course of treatment and there was microbiological or histological evidence of active tuberculosis at the moment of death.

\section{RESULTS}

Among 1005 liver transplant recipients on current cumulative follow-up, eight liver transplant recipients developed active TB (Table 1).

Most were men $(62.5 \%)$, with a mean age of 53.5 years (38 - 72 years). Most TB cases were diagnosed more than 12 months after liver transplantation $(6 ; 75 \%)$. The mean time between liver transplant and TB diagnosis was 61.5 months (median 39.1; range 5.6 - 229.1 months). The most frequently reported symptom was fever $(5 ; 62.5 \%)$, along with constitutional symptoms $(3 ; 37.5 \%)$. Only one patient was asymptomatic, in which case TB diagnosis was done during study of a solitary lung nodule detected on a routine chest X-ray.

The mean duration of symptoms before TB diagnosis was 4.6 months (median 3.1 ; range 0.8 - 13 months).

Table 1 - Demographic and clinical characteristics of liver transplant recipients with tuberculosis

\begin{tabular}{|c|c|c|c|c|c|c|}
\hline $\begin{array}{l}\text { Patient } n^{\circ} \\
\text { (age, sex) }\end{array}$ & LT year & $\begin{array}{l}\text { Underlying } \\
\text { disease }\end{array}$ & $\begin{array}{c}\text { TB } \\
\text { diagnosis }\end{array}$ & $\begin{array}{l}\text { Mean time to } \\
\text { TB diagnosis } \\
\text { after LT }(\mathrm{m})\end{array}$ & Immunosuppresion & TB risk factors \\
\hline $\begin{array}{l}1 \\
(49, \text { male })\end{array}$ & 2008 & $\mathrm{HCV}$ & 2014 & 64.3 & Cyclosporine & None \\
\hline $\begin{array}{l}2 \\
(46, \text { male })\end{array}$ & 2012 & $\begin{array}{l}\text { Alcoholic } \\
\text { cirrhosis, HBV }\end{array}$ & 2013 & 5.6 & Tacrolimus and MMF & Long stay in Africa before LT \\
\hline $\begin{array}{l}3 \\
(42, \text { male })\end{array}$ & 2012 & $\begin{array}{l}\text { Sclerosing } \\
\text { cholangitis }\end{array}$ & 2014 & 16.8 & Tacrolimus and MMF & None \\
\hline $\begin{array}{l}4 \\
(57, \text { male })\end{array}$ & 2013 & $\begin{array}{l}\text { Alcoholic } \\
\text { cirrhosis, HCC }\end{array}$ & 2014 & 9.5 & Tacrolimus and MMF & None \\
\hline $\begin{array}{l}5 \\
(72, \text { male })\end{array}$ & 2006 & $\mathrm{HCV}, \mathrm{HCC}$ & 2014 & 88.6 & Everolimus & $\begin{array}{l}\text { Radiological evidence of } \\
\text { past tuberculosis }\end{array}$ \\
\hline $\begin{array}{l}6 \\
(53, \text { female })\end{array}$ & 2008 & $\begin{array}{l}\text { Primary biliary } \\
\text { cirrhosis }\end{array}$ & 2013 & 56.0 & Sirolimus & None \\
\hline $\begin{array}{l}7 \\
(38, \text { female })\end{array}$ & $\begin{array}{l}1^{\text {st }}-1991 \\
2^{\text {nd }}-2006\end{array}$ & $\begin{array}{l}\text { Auto-immune } \\
\text { hepatitis }\end{array}$ & 2010 & $229.0^{*}$ & Tacrolimus and MMF & None \\
\hline $\begin{array}{l}8 \\
(71, \text { female })\end{array}$ & 2013 & $\begin{array}{l}\text { Alcoholic } \\
\text { cirrhosis }\end{array}$ & 2014 & 22.0 & Tacrolimus & $\begin{array}{l}\text { Radiological evidence of } \\
\text { past tuberculosis and contact } \\
\text { with a familiar case of TB }\end{array}$ \\
\hline
\end{tabular}


Four patients presented pulmonary tuberculosis, one of them with disseminated disease. There was another case of disseminated disease, without pulmonary findings. The remaining three patients had pleural $(n=2)$ and intestinal disease $(n=1)$.

In one of the two cases of disseminated TB there was involvement of the graft liver, demonstrated by the presence of granulomas containing acid-fast bacilli on liver biopsy obtained during exploratory laparotomy. None of the patients had acid-fast bacilli on sputum smear. All cases required invasive diagnostic procedures. In seven cases $(87.5 \%)$ there was cultural isolation of $M$. tuberculosis complex; in the remaining case the diagnosis was based on the presence of acid-fast bacilli on pleural biopsy. None of the isolates were resistant to first-line anti-tuberculosis drugs and induction treatment was initiated with a four-drug regimen containing isoniazid, rifampin, pyrazinamide and ethambutol in all cases.

Four patients had elevated liver enzymes throughout the course of treatment $(50 \%)$. In only one case were these changes attributable to antibacillary drugs toxicity. In two patients, liver biopsy showed acute rejection and in the remaining one, changes were attributable to Hepatitis $B$ virus (HBV) reactivation.

Three patients presented simultaneous infections. One patient had HBV reactivation, one had positive cytomegalovirus (CMV) antigenemia, which prompted preemptive treatment and another one had pneumonia due to Pneumocystis jirovecii (PPC). This last patient died.

Crude mortality during follow up was $37.5 \%$, while mortality directly attributable to TB was $25 \%$.

\section{DISCUSSION}

Incidence of tuberculosis in solid organ transplant recipients has been reported to range from 0.35 to $15 \%,{ }^{1}$ hence being eight to 100 -fold higher than among general population in the respective countries..$^{1,6,7}$ TB incidence in liver transplant recipients ranges from $0.9 \%$ to $2.3 \% .^{2,8}$ In Portugal, TB incidence ranged from 20 to 22 cases per 100000 inhabitants during the period analyzed.

In this case series the frequency of TB in liver transplant recipients was $0.8 \%$. Even though this report doesn't allow us to estimate the incidence of TB in liver transplant recipients in Portugal, this frequency is important, since the short-term mortality rate for liver transplant recipients with active tuberculosis is $31 \%$. $^{1,9-11}$ Although about two-thirds of reported cases of active tuberculosis disease in transplant recipients occur early, commonly defined as the first posttransplant year, ${ }^{1,7,8}$ in our study late-onset TB infection, defined as disease occurring after the first twelve months pos-transplantation, was more frequent $(n=6 ; 75 \%)$.

It has been suggested that patients with prior clinical or radiological evidence of tuberculosis tend to develop the disease earlier than patients without these

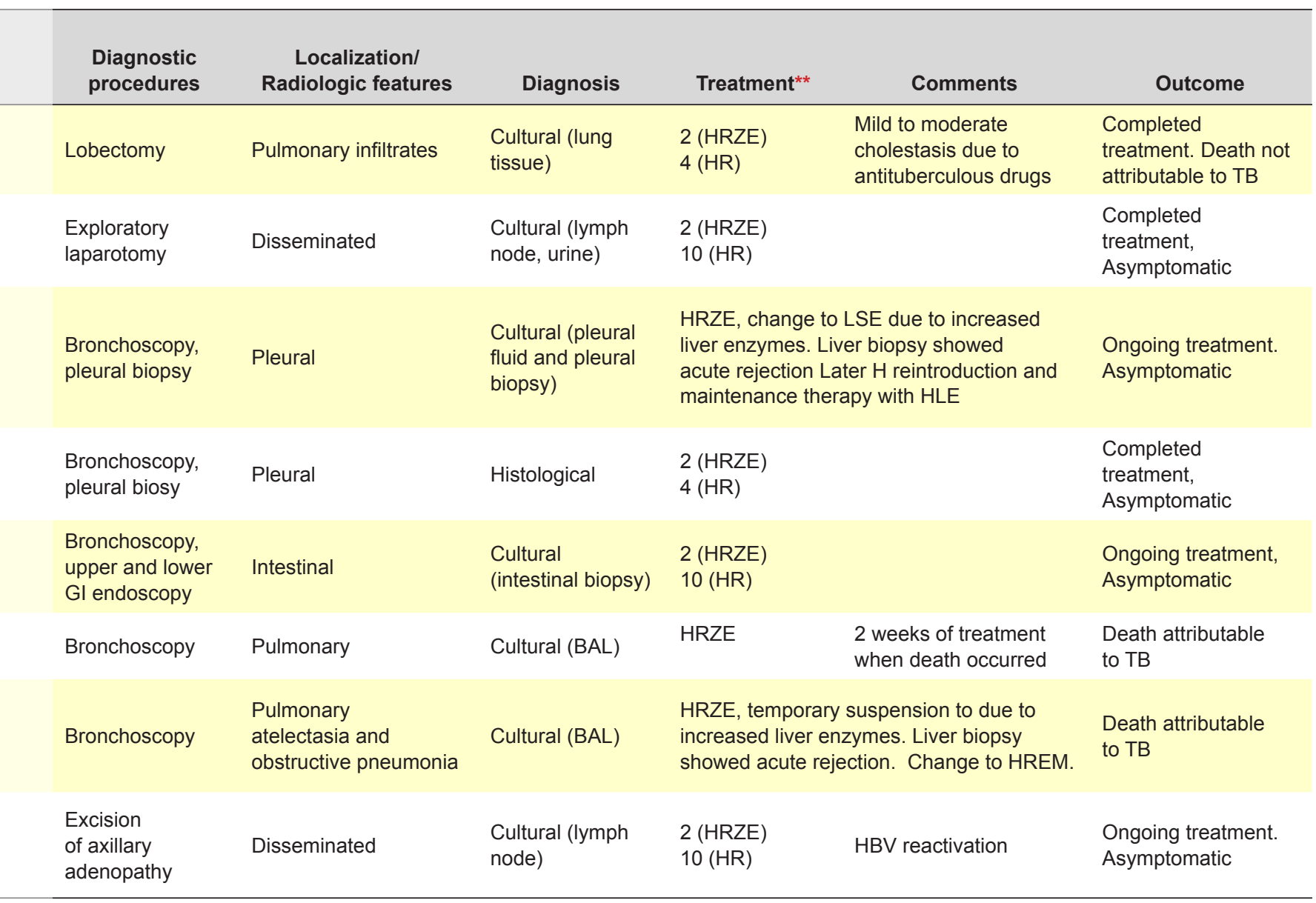




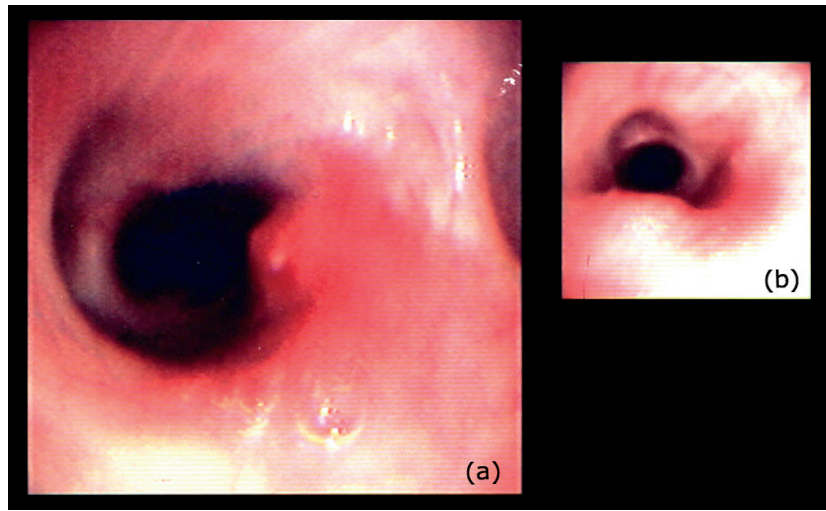

Figure 1 - Main right bronchius showing a nipple-like lesion with a mucosal hyperemia

antecedents, due to higher risk of reactivation during the first months after transplantation, independent of the type of immunosuppression received. ${ }^{12-14}$ However, in our report, none of the patients with TB risk factors who developed late TB disease were treated for latent TB infection. Also, as shown in Table 1, patients with radiographic changes that could suggest past TB infection developed active disease more than 1 year after liver transplantation.

Primary tuberculosis infection in liver transplant recipients is not frequently reported in the literature. However, we think that patient seven, who had pulmonary atelectasy and obstructive pneumonia with endobronchial tuberculosis seen in the bronchoscopy may have very likely had primary TB, since the radiological and endoscopic features presented by this patient are usually described as highly suggestive of primary disease (Fig. 1).

The most frequent clinical presentation of TB in our study was nonspecific fever and constitutional symptoms, which is in accordance to other case series..$^{3,5,12,13}$ Fever is significantly more likely to occur in transplant recipients with disseminated infection than in those with localized tuberculosis. ${ }^{1}$ Although pulmonary TB occurs in more than $50 \%$ of transplant recipients, disseminated forms are frequently reported. ${ }^{1,4,10}$ Similarly to other series,

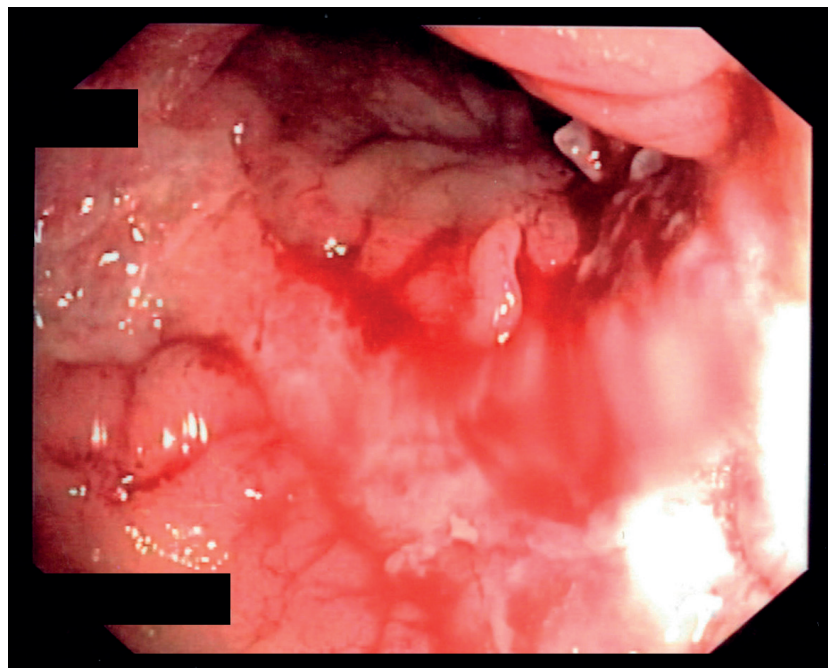

Figure 2 - Longitudinal ulcer and cobblestone appearance at the distal third of transverse colon approximately $37 \%$ of our cases were disseminated or occurred at extra-pulmonary sites.

In our case series we highlight the tuberculous involvement of the graft liver in one patient (patient two) and the case of intestinal tuberculosis (patient five), in which cardinal symptoms were fever, anemia and weight loss. In this last case, diagnosis was particularly difficult to establish and the patient underwent three colonoscopies that showed multiple ulceration and significant ileum disease (Fig.s 2 5).

All patients were treated with a four-drug induction regimen for two months. This drug scheme was changed to a free-rifampin regimen in the two patients that had acute graft rejection (Table 1). After induction regimen, the remaining patients were treated with a two-drug maintenance regimen with isoniazid and rifampin during four or 10 months, depending on disease severity and extension.

Despite the uncertainty regarding treatment duration in liver transplant recipients, disease severity, as well as number of active drugs against TB infection, should be taken into account. ${ }^{15}$ In our case series, patients with pulmonary TB were treated for six months and the remaining for 12 months.

Rifampin is a strong inducer of the microsomal enzymes that metabolize cyclosporine and tacrolimus, which poses a major difficulty in the treatment of transplant recipients with tuberculosis ${ }^{1}$ and may complicate the maintenance of adequate levels of immunossuppressive drugs. Hence, during TB treatment in transplant recipients, liver function tests must be closely monitored and dosages of cyclosporine and tacrolimus should be adequately adjusted, usually requiring an increase of at least 2 - 3 fold. The decrease in serum levels of calcineurin inhibitors and corticosteroids caused by rifampin has been associated with a high risk of graft rejection that may be up to $25 \% .^{12}$

In this case series, two patients with liver enzyme elevation had acute rejection confirmed by liver biopsy. Both acute rejection episodes occurred during the first month of antibacillary treatment and were very likely due

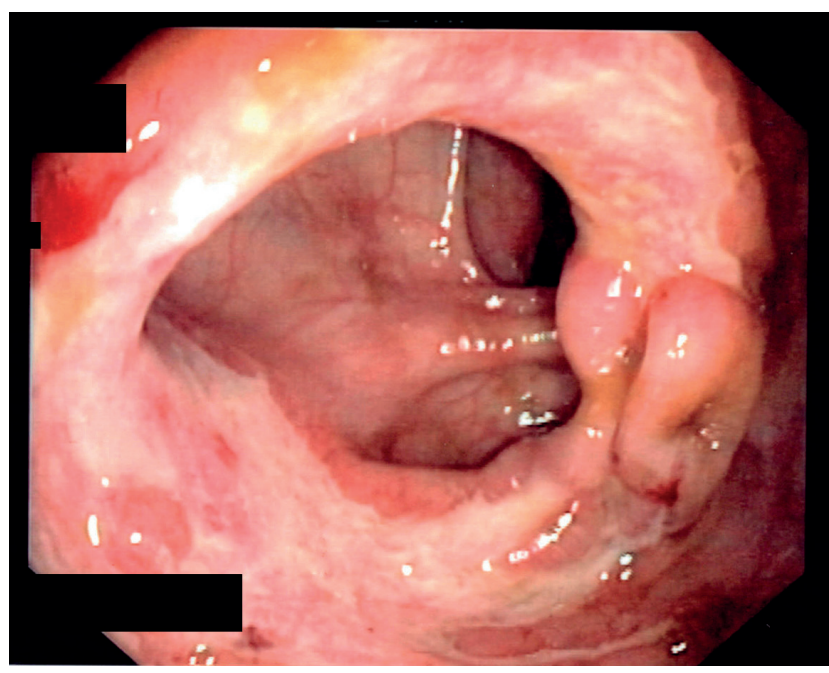

Figure 3 - Ulcer with a polypoid lesion at the proximal third of the transverse colon 


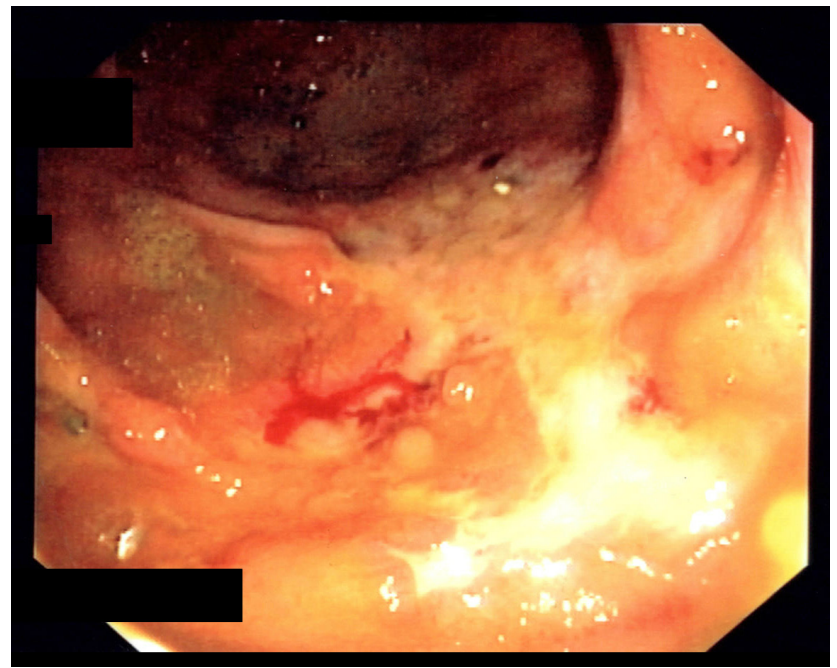

Figure 4 - Ulcers with a purulent exudate at the ascending colon

to low tacrolimus levels and not tuberculosis treatment. Our approach in this two cases consisted in immunosuppression adjustment and change to an antibacillary rifampin-free regimen.

In our series crude mortality was $37.5 \%$, while mortality directly attributable to TB was $25 \%$. Both deaths registered in our case series occurred in patients with pulmonary TB. In patient seven, simultaneous PPC contributed to the non-favorable outcome. In the other one, regrettably, post mortem examination was not possible, and the presumable cause of sudden death was most likely cardiovascular, since the patient had obesity, diabetes and pulmonary hypertension.

In our transplantation unit, skin testing with purified protein derivative (PPD) is usually reserved for patients with prior clinical or chest X-ray findings suggestive of past TB. Hence, we had no sufficient data in order to characterize the impact of this feature in our case report throughout the period analyzed. However, it is important to underline that transplant recipients with a positive PPD test have a relative risk of 4.3 of developing symptomatic TB. ${ }^{11}$ Also, liver transplant recipients have an 18-fold increased risk of TB reactivation in comparison with the general population and even possibly higher in areas with high incidence of $\mathrm{TB},{ }^{16}$ as was the case of Portugal during the period in question, during which TB incidence ranged from 20 to 22 cases per 100000 inhabitants. ${ }^{17-19}$ European guidelines now recommend that all transplant candidates should have a tuberculin test or a TB interferon-gamma release assay (IGRA) test carried out in order to decide chemoprophylaxis. ${ }^{20}$

\section{CONCLUSION}

In conclusion, despite limitations inherent to the study design, we present a review of TB cases in a large

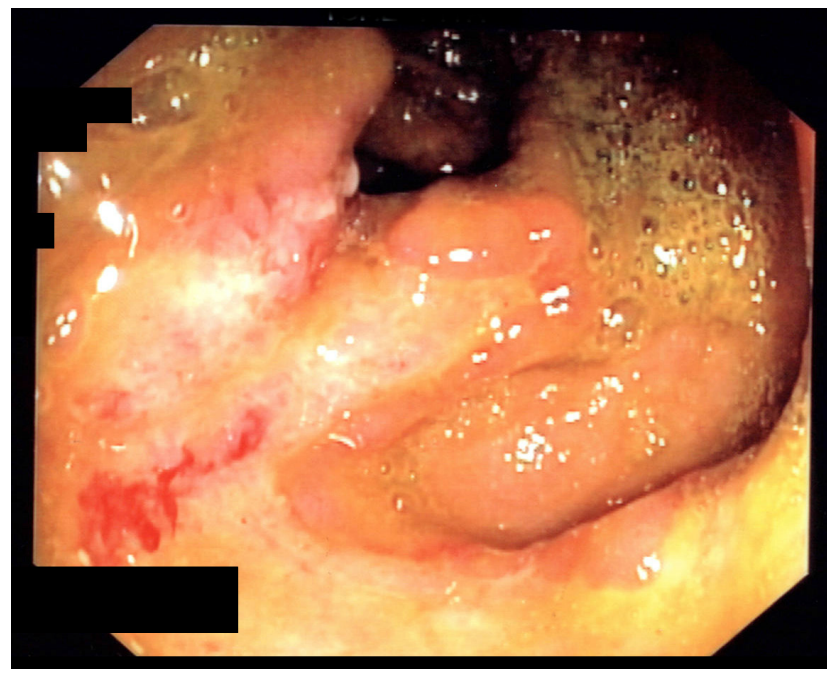

Figure 5 - Ulcers and cobblestone appearance at the proximal ascending colon

series of liver transplant recipients. During this 5-year period, eight patients developed active TB infection and the observed mortality rate was not to be neglected. The reported tendency to non-pulmonary disseminated TB illustrates the challenge in diagnosing TB infection in liver transplant recipients, as well as the need to perform early invasive diagnostic procedures. Although the number of patients is small, it is worth noticing that none of the eight patients had lung cavitation, as this has been described to be a rare feature in solid organ transplant recipients. ${ }^{13}$ The cases of drug toxicity and acute graft rejection reflect the difficulties in the management of interactions between immunosuppressors and rifampin. Our study also strengthens the recommendation of latent TB infection screening and treatment in liver transplant candidates or recipients.

\section{PROTECTION OF HUMANS AND ANIMALS}

The authors declare that the procedures were followed according to the regulations established by the Clinical Research and Ethics Committee and to the Helsinki Declaration of the World Medical Association.

\section{DATA CONFIDENTIALITY}

The authors declare having followed the protocols in use at their working center regarding patients' data publication.

\section{CONFLICTS OF INTEREST}

The authors declare that there are no conflicts of interest.

\section{FUNDING SOURCES}

No subsidies or grants contributed to this work. 
chemoprophylaxis administered during liver transplant candidacy for the prevention of posttransplant tuberculosis. Transplantation. 2002;74:8925.

3. Muñoz P, Rodríguez C, Bouza E. Mycobacterium tuberculosis infection in recipients of solid organ transplants. Clin Infect Dis. 2005;40:581-7.

4. John GT, Shankar V, Abraham AM, Mukundan U, Thomas PP, Jacob CK. Risk factors for post-transplant tuberculosis. Kidney Int. 2001;60:114853.

5. Fishman JA. Infection in solid-organ transplant recipients. N Engl J Med. 2007;357:2601-14.

6. Chan AC, Lo CM, Ng KK, Chan SC, Fan ST. Implications for management of Mycobacterium tuberculosis infection in adult-to-adult live donor liver transplantation. Liver Int. 2007;27:81-5.

7. Lopez de Castilla D, Schluger NW. Tuberculosis following solid organ transplantation. Transpl Infect Dis. 2010;12:106-12.

8. Clemente WT, Faria LC, Lima SS, Vilela EG, Lima AS, Velloso LF, et al. Tuberculosis in liver transplant recipients: a single Brazilian center experience. Transplantation. 2009;87:397-401.

9. Holty JE, Gould MK, Meinke L, Keeffe EB, Ruoss SJ. Tuberculosis in liver transplant recipients: a systematic review and meta-analysis of individual patient data. Liver Transpl. 2009;15:894-906.

10. Subramanian A, Dorman S, AST Infectious Diseases Community of Practice. Mycobacterium tuberculosis in solid organ transplant recipients. Am J Transplant. 2009;9:S57-62.

11. Torre-Cisneros J, Doblas A, Aguado JM, San Juan R, Blanes M, Montejo $M$, et al. Tuberculosis after solid-organ transplant: incidence, risk factors, and clinical characteristics in the RESITRA (Spanish Network of Infection in Transplantation) cohort. Clin Infect Dis. 2009;48:1657-65.

12. Aguado JM, Herrero JA, Gavaldá J, Torre-Cisneros J, Blanes M, Ruf $\mathrm{G}$, et al. Clinical presentation and outcome of tuberculosis in kidney, liver, and heart transplant recipients in Spain. Spanish Transplantation Infection Study Group, GESITRA. Transplantation. 1997;63:1278-86.

13. Zhang XF, Lv Y, Xue WJ, Wang B, Liu C, Tian PX, et al. Mycobacterium tuberculosis infection in solid organ transplant recipients: experience from a single center in China. Transplant Proc. 2008;40:1382-5.

14. Joo DJ, Kim BS, Kim SJ, Huh KH, Kim MS, Ju MK, et al. Risk factors and characteristics of post-transplant tuberculosis in an endemic area. Ann Transplant. 2013;18:163-73.

15. Meije Y, Piersimoni C, Torre-Cisneros J, Dilektasli AG, Aguado JM, ESCMID Study Group of Infection in Compromised Hosts. Mycobacterial infections in solid organ transplant recipients. Clin Microbiol Infect. 2014;20:89-101.

16. Fábrega E, Sampedro B, Cabezas J, Casafont F, Mieses MÁ, Moraleja I, et al. Chemoprophylaxis with isoniazid in liver transplant recipients. Liver Transpl. 2012;18:1110-7.

17. Direcção Geral de Saúde. Programa Nacional para a Infecção VIH/ SIDA. Portugal. Infecção por VIH, SIDA e Tuberculose em números 2015. Novembro 2015; [consultado 2016 mai 2]. Disponível em: http:// www.dgs.pt/?cr=29118.

18. Macedo R, Santos Silva A, Rodrigues IJ, Rodrigues I, Furtado C, Simões MJ. Vigilância Nacional da Tuberculose. INSA, IP. Dezembro 2013; [consultado 2015 fevereiro 25]. Disponível em: http://repositorio.insa.pt/ bitstream/10400.18/1881/6/Vigilancia_Laboratorial_da_Tuberculose_ em_Portugal-Relatorio_2012.pdf.

19. Direcção Geral de Saúde. Programa Nacional para a Infecção VIH/ SIDA em Portugal - Infecção VIH, SIDA e Tuberculose em números - 2014. Dezembro 2014; [consultado 2015 fev 25]. Disponível em; http://www.google.pt/url?sa=t\&rct=j\&q=\&esrc=s\&source=web\&cd=1\&v ed=0CCEQFjAA\&url=http $\% 3 A \% 2 F \% 2 F w w w . d g s . p t \% 2 F e s t a t i s t i c a s-d e-$ saude $\% 2$ Festatisticas-de-saude $\% 2$ Fpublicacoes $\% 2 F$ portugal-infecaovih-sida-e-tuberculose-em-numeros-2014-pdf.aspx\&ei=KkHuVMLEHob 1UsjDgPAP\&usg=AFQjCNGtxb1WdoCEVUK1rAaUdfB5Ykv3oQ\&sig2= Vzdjlanwv23ULIjQDBB-Cg\&bvm=bv.86956481,d.d24\&cad=rja.

20. Len O, Garzoni C, Lumbreras C, Molina I, Meije Y, Pahissa A, et al. ESCMID Study Group of Infection in Compromised Hosts. Recommendations for screening of donor and recipient prior to solid organ transplantation and to minimize transmission of donor-derived infections. Clin Microbiol Infect. 2014;20:10-8. 